\title{
Increasing the attractiveness of investment projects in the mining industry of the Russian Far East
}

\author{
Yuliya Arkhipova ${ }^{1 *}$ and Rudolf Leontiev ${ }^{2 * *}$ \\ ${ }^{1}$ Mining Institute FEB RAS, 51 Turgenev st., Khabarovsk, 680000, Russia \\ ${ }^{2}$ Computing Center FEB RAS; RF. 680000, Khabarovsk, st. Kim Yoo Chen, 65
}

\begin{abstract}
The article is devoted to the issue of the possibility of economic development of the mining industry in the subjects of the Far Eastern Federal District (FEFD) and the impact of investment projects. With the vast wealth and diversity of mineral resources, their involvement in the national economy is an essential factor in the industrialization and successful development of the regions. In the case of the establishment of processing plants, for a number of minerals, the region could provide its own needs, as well as the countries, finished products from it, and develop an export focus. The article considers the export orientation of the mineral and raw materials complex of Russia and the constituent entities of the Russian Federation, as well as the commodity structure of exports of the regions of the FEFD. Special attention is paid to the implementation of major regional investment projects, which are important for the development of the regions. So, it is proposed to implement a major project in the form of an integrated mining and metallurgical complex due to the fact that the region needs its own ferrous metallurgy. The calculations carried out (in various versions: basic, in the conditions of the territory of advanced development (TAD), without the costs of infrastructure creation) showed that the implementation of the project is cost-effective, but due to the high costs, the support of the state is necessary.
\end{abstract}

\section{Introduction}

The attractiveness of the Far East for investment, and therefore the possibility of economic development, is determined by a complex of factors, an important place among which is natural resource capital. Despite the ambiguity in assessing the impact of natural capital (including mineral resources) on economic growth, for many regions it is an important factor in industrialization and successful development [1]. That is why the topic of the article, which examines the impact of investment projects in the mining industry on the development of the economy of the Far Eastern region of the Russian Federation, is so relevant at present. The implementation of effective projects in the mineral resource complex can serve as a "locomotive" for the development of the economy and social sphere of this region.

The special feature of the Far East is that with the enormous wealth and diversity of mineral resources, their involvement in the national economy can fundamentally change the socio-economic situation in the region. But there is a difficulty - it is the relative distance of

\footnotetext{
* Main author:arhipova@igd.khv.ru

** Corresponding author: rleontyev1@mail.ru
} 
cooperation with the countries of the Asia-Pacific region.

\section{Materials and methods}

Consider the export orientation of the mineral resource complex (MSC) of Russia. Recently, there has been a positive dynamics of gross domestic product and an increase in the country's exports, which was facilitated by the favorable global commodity price environment. In the short term, this can lead to positive results for the country's economy. But, as world experience shows, the dependence of the economy on the export of commodities does not contribute to economic growth in the long term due to the instability of world prices for raw materials [2].

In the context of globalization, exports began to largely determine the development of not only certain sectors of the national economy, but also the economy as a whole. The government is committed to ensuring the sustained expansion of long-term foreign sales. To this end, national export strategies and programs are being developed containing some new and generally more aggressive approaches to export promotion.

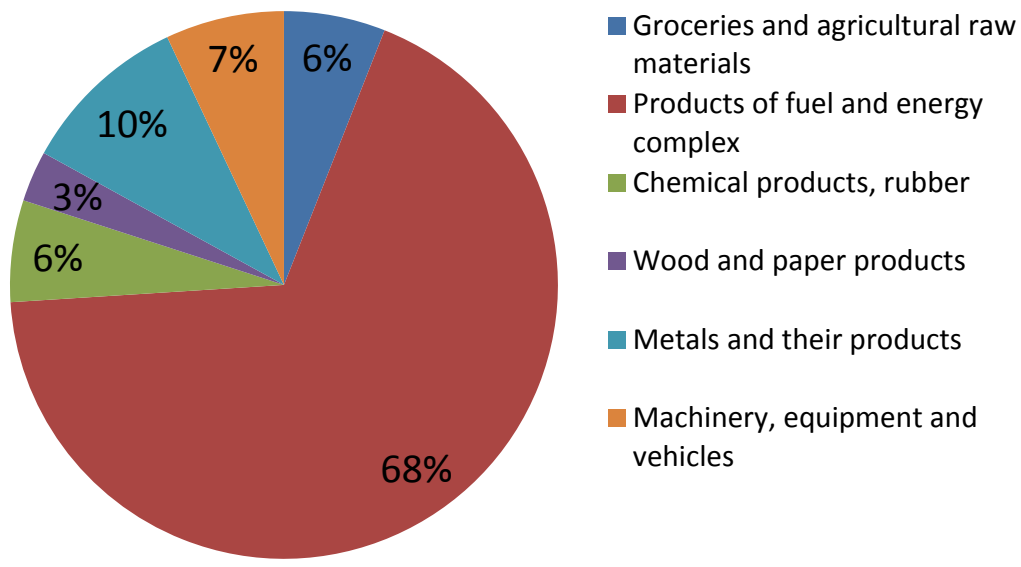

Fig. 1. Commodity structure of export of the Russian Federation in 2018, \% [4]

The volume of Russian merchandise exports in value terms in 2018 reached 424.02 billion US dollars and grew by 2.33 times compared to 2004 [3]. Between 2009 and 2018 there is a gradual increase with periodic fluctuations associated with various situations in the world, including export restrictions imposed by sanctions, etc. Nevertheless, $68 \%$ falls on the products of the fuel and energy complex, $10 \%$ - on metals and products from them, with a small share of engineering products in exports - 7\% (Fig. 1).

That is, the commodity structure of Russian exports remains unsatisfactory. The prevalence of raw materials and the low share of finished products in exports clearly does not correspond to the status of the industrialized country.

The wealth of natural resources of the Far Eastern Federal District (FEFD) is, in essence, its advantage. So, a significant share in the all-Russian balance of reserves and production are: gold (reserves $33 \%$ and production $44 \%$ ), silver (35\% and $65 \%$ ), platinum (production - more than $15 \%$ for platinum, about $4 \%$ platinoids). Non-ferrous metals: tin (92\% and $99 \%)$, tungsten $(23 \%$ and $79 \%)$, lead $(10 \%$ and $38 \%)$, antimony $(82 \%$ and $100 \%$ ), bismuth (32\% and $48 \%$ ), germanium (64\% and $95 \%)$. Mining raw materials: boron (100\% and $100 \%)$, hydrofluoric spar $(40 \%$ and $82 \%)$, volcanic glass $(27 \%$ and $71 \%)$, zeolites (12\% and $88 \%$ ) [5]. The comparative advantage of other regions less rich in natural resources should be the development of manufacturing, processing and high-tech industries [6]. 
district (PFD) and North-West federal districts (NWFD), they account for 4687.7 and 4145.5 million dollars, or 16.08 and $14.22 \%$, respectively (Table 1 ). FEFD is in fifth place and amounts to $\$ 1502.1$ million, i.e. $5.15 \%$.

Table 1. Export of products of constituent entities of the Russian Federation by sectors of 2018, \$ million*

\begin{tabular}{|l|c|c|c|c|c|c|}
\hline \multirow{2}{*}{$\begin{array}{c}\text { Subjects of the } \\
\text { Russian } \\
\text { Federation }\end{array}$} & $\begin{array}{c}\text { Products of the } \\
\text { fuel and energy } \\
\text { complex }\end{array}$ & \multicolumn{2}{c|}{$\begin{array}{c}\text { Metals and } \\
\text { products from } \\
\text { them }\end{array}$} & \multicolumn{2}{c|}{$\begin{array}{c}\text { Machines, } \\
\text { equipment, } \\
\text { vehicles }\end{array}$} \\
\cline { 2 - 7 } million \$ & \% & million \$ & \% & million \$ & \% \\
\hline RF, total & 286998.7 & 100 & 43633.8 & 100 & 29146.3 & 100 \\
\hline Central FD & 173288.1 & 60.38 & 11551 & 26.47 & 13943.3 & 47.84 \\
\hline North-West FD & 24274.3 & 8.46 & 7290.3 & 16.71 & 4145.5 & 14.22 \\
\hline Southern FD & 7319.9 & 2.55 & 1934 & 4.43 & 802.4 & 2.75 \\
\hline $\begin{array}{l}\text { North Caucasian } \\
\text { FD }\end{array}$ & 66.9 & 0.02 & 140.7 & 0.32 & 40.5 & 0.14 \\
\hline Privolzhskij FD & 21249.6 & 7.40 & 3406.8 & 7.81 & 4687.7 & 16.08 \\
\hline Ural FD & 25692.8 & 8.95 & 8734.9 & 20.02 & 2667.2 & 9.15 \\
\hline Siberian FD & 18093.5 & 6.30 & 10032.5 & 22.99 & 1357.6 & 4.66 \\
\hline Far Eastern FD & 17013.6 & 5.93 & 543.6 & 1.25 & 1502.1 & 5.15 \\
\hline
\end{tabular}

* Compiled by source [4]

It would seem that in the export of commodities, the richer districts with natural resources should lead. But the data show that in the first place in the export of energy carriers is the Central Federal District, whose share in the export of products of the fuel and energy complex of the Russian Federation was, according to 2018, 60.38\%. This can be explained by the fact that it is in Moscow that the head companies of the largest producers of energy products are registered. This is followed by the Ural Federal District (Ural Federal District) and the NWFD, which account for 8.95 and $8.46 \%$ of the exported fuel and energy raw materials of Russia. FEFD in sixth place - 5.93\%. In the export of metals and products from them, FEFD in seventh place $-1.25 \%$.

However, the analysis of the contribution of federal districts to Russian exports by industry is incomplete and should be supplemented by an analysis of the export structure and industry specialization of each federal district. Thus, fuel and energy products predominate in the structure of export of goods to the Central Federal District $(80.8 \%)$, the share of engineering products is insignificant and amounts to $6.5 \%$ (Table 2).

In the structure of export of the Far East, the products of the fuel and energy complex dominate $-70.3 \%$, followed by food products and agricultural raw materials $-15.6 \%$ and a low percentage of the engineering industry $-6.2 \%$. These figures confirm the assertion that at present the Far Eastern Federal District continues to remain a raw-material region.

The regions where export of fuel and energy complex products predominate include: Republics of Buryatiya and Sakha (Yakutiya), Zabaykalskiy kraj, Sahalinskaya oblast and Chukotskij avtonomniy okrug. In Khabarovskiy kraj - mechanical engineering and vehicles (29.8\%). Export of metals and products from them is $9.3 \%$ in Khabarovskiy kraj, and $6.7 \%$ in Primorskiy kraj, in other regions this indicator is too low. 


\begin{tabular}{|l|c|c|c|c|c|c|c|}
\hline Central FD & 100.0 & 3.1 & 80.8 & 3.5 & 0.8 & 5.4 & 6.5 \\
\hline North-West FD & 100.0 & 7.0 & 50.1 & 9.1 & 10.2 & 15.0 & 8.5 \\
\hline Southern FD & 100.0 & 42.8 & 37.3 & 5.1 & 0.9 & 9.8 & 4.1 \\
\hline North Caucasian FD & 100.0 & 30.7 & 5.8 & 46.9 & 0.9 & 12.2 & 3.5 \\
\hline Privolzhskij FD & 100.0 & 2.9 & 50.8 & 23.7 & 3.3 & 8.1 & 11.2 \\
\hline Ural FD & 100.0 & 0.7 & 67.5 & 6.1 & 1.0 & 17.7 & 7.0 \\
\hline Siberian FD & 100.0 & 2.5 & 50.2 & 4.4 & 11.3 & 27.8 & 3.8 \\
\hline Far Eastern FD & 100.0 & 15.6 & 70.3 & 0.3 & 5.4 & 2.2 & 6.2 \\
\hline
\end{tabular}

* Compiled by source [4]

$\mathrm{X}_{1}-$ Groceries and agricultural raw materials

$\mathrm{X}_{2}$ - Products of the fuel and energy complex

$\mathrm{X}_{3}$ - Chemical industry products, rubber

$\mathrm{X}_{4}$ - Products of the wood and pulp and paper

$\mathrm{X}_{5}$ - Metals and products from them

$\mathrm{X}_{6}$ - Machines, equipment and vehicles

We also supplement the studies with an intraregional analysis of the commodity structure of the Far East (Table 3).

Table 3. Commodity structure of export of the Far Eastern Federal District by region in 2018, \% *

\begin{tabular}{|l|c|c|c|c|c|c|c|}
\hline Regions of the Far Eastern Federal District & Total, $\%$ & $\mathbf{X}_{\mathbf{1}}$ & $\mathbf{X}_{\mathbf{2}}$ & $\mathbf{X}_{\mathbf{3}}$ & $\mathbf{X}_{\mathbf{4}}$ & $\mathbf{X}_{\mathbf{5}}$ & $\mathbf{X}_{\mathbf{6}}$ \\
\hline Republic of Buryatiya & 100.0 & 1.9 & 68.6 & 0.5 & 16.3 & 1.3 & 11.4 \\
\hline Republic of Sakha (Yakutiya) & 100.0 & 0.1 & 97.9 & 0.0 & 0.0 & 0.0 & 1.9 \\
\hline Zabaykalskiy kraj & 100.0 & 15.6 & 40.2 & 11.7 & 32.1 & 0.2 & 0.2 \\
\hline Kamchatkiy kraj & 100.0 & 98.7 & 0.6 & 0.0 & 0.0 & 0.5 & 0.2 \\
\hline Primorskiy kraj & 100.0 & 46.9 & 19.6 & 1.3 & 12.4 & 6.7 & 13.1 \\
\hline Khabarovskiy kraj & 100.0 & 11.9 & 23.0 & 0.3 & 25.7 & 9.3 & 29.8 \\
\hline Amurskaya oblast & 100.0 & 45.7 & 44.9 & 0.4 & 8.8 & 0.0 & 0.2 \\
\hline Magadanskaya oblast & 100.0 & 98.3 & 0.0 & 0.0 & 0.0 & 1.0 & 0.7 \\
\hline Sahalinskaya oblast & 100.0 & 5.3 & 93.0 & 0.0 & 0.0 & 0.5 & 1.3 \\
\hline Evrejskaya avtonomnaya oblast & 100.0 & 75.0 & 0.4 & 0.2 & 24.1 & 0.0 & 0.4 \\
\hline Chukotskij avtonom. okrug & 100.0 & 18.2 & 79.3 & 0.0 & 0.0 & 0.0 & 2.5 \\
\hline
\end{tabular}

* Compiled by source [4]

The regions of the Far East, on the one hand, have the richest mineral resources, and, on the other hand, are characterized by a mismatch in the level of development of productive forces, as well as transport and energy infrastructure, with the potential of natural resources. This leads to a significant lag in social and economic development compared to other regions of Russia, to an increase in the outflow of the population and the emergence of other systemic problems. The presence of large reserves of oil, coal, ferrous, non-ferrous and rare-earth metals, as well as geographical proximity to the rapidly developing countries of the Asia-Pacific region, including China, suggest that further development of the Far East will be associated with the intensification and intensification of economic relations with Southeast Asian countries. However, it cannot be ruled out that the natural wealth of these regions may become the main resource and financial base for the development of various industries and agriculture while reorienting the economy to the industrial development path. The full use of the wealth of the Far East for the production of goods 
natural resources.

Table 4 presents the currently implemented investment projects of the Far Eastern Federal District related to the development of iron ore deposits or the creation of mining and metallurgical enterprises on their basis, as well as the development of tin ore deposits. These two areas were chosen due to the fact that the creation of a metallurgical plant with the production of products of a high degree of redistribution is one of the most important components of economic stability in the region. At the same time, there is a real supply of iron ore. And tin - because more than $95 \%$ of its reserves and resources are concentrated precisely in the Far East. So, according to the table, it can be seen that the percentage of budget (federal) funds in projects of particular importance is extremely low and mainly financing is provided at the expense of the investor.

Table 4. Characteristics of investment projects in the Far Eastern Federal District

\begin{tabular}{|c|c|c|c|c|c|c|}
\hline \multirow{3}{*}{$\begin{array}{l}\text { Project, } \\
\text { subject of the FEFD }\end{array}$} & \multicolumn{3}{|c|}{$\begin{array}{c}\text { Financial resources, } \\
\text { billion rubles }\end{array}$} & \multirow{3}{*}{$\begin{array}{l}\text { Share } \\
\text { B,\% }\end{array}$} & \multirow{3}{*}{$\begin{array}{l}\text { Number } \\
\text { of jobs } \\
\text { created }\end{array}$} & \multirow{3}{*}{ Investor } \\
\hline & \multirow[b]{2}{*}{ Total } & \multicolumn{2}{|c|}{ including: } & & & \\
\hline & & $\begin{array}{l}\text { investor } \\
\text { (I) }\end{array}$ & $\begin{array}{c}\text { budget } \\
\text { (B) }\end{array}$ & & & \\
\hline $\begin{array}{l}\text { Construction of mining and } \\
\text { metallurgical plant (iron } \\
\text { ore concentrate), } \\
\text { Kamchatskiy Kraj }\end{array}$ & 28 & 27.2 & 0.8 & $0.03 *$ & 150 & $\begin{array}{l}\text { Petropavlovsk- } \\
\text { Kamchatsky Processing } \\
\text { Plant LLC }\end{array}$ \\
\hline $\begin{array}{l}\text { Development of Garinskoe } \\
\text { iron ore deposit and } \\
\text { construction of mining and } \\
\text { processing plant, } \\
\text { Amurskaya oblast }\end{array}$ & 48.5 & 21.3 & 27.2 & 0.56 & 1485 & $\begin{array}{l}\text { "Petropavlovsk," LLC } \\
\text { "Garinsky MMK," LLC } \\
\text { "Petropavlovsk-Black } \\
\text { Metallurgy" }\end{array}$ \\
\hline $\begin{array}{l}\text { Creation of a mining and } \\
\text { metallurgical cluster in the } \\
\text { Priamur'e, Evrejskaya } \\
\text { avtonomnaya oblast }\end{array}$ & 25.4 & 24.9 & 0.5 & 0.02 & 1562 & $\begin{array}{l}\text { LLC Kimkano-Sutarsky } \\
\text { GOK }\end{array}$ \\
\hline $\begin{array}{l}\text { Development of the placer } \\
\text { tin deposit on the } \\
\text { Tirekhtyakh stream, } \\
\text { Republic of Sakha } \\
\text { (Yakutiya) }\end{array}$ & 1.1 & 0 & 0 & $0^{*}$ & 85 & $\begin{array}{l}\text { JSC Yanolovo, JSC South } \\
\text { Yakutiya Development } \\
\text { Corporation }\end{array}$ \\
\hline $\begin{array}{l}\text { Construction of Mining and } \\
\text { Processing Plant of } \\
\text { Pravurmia Tin Ore Field, } \\
\text { Khabarovskiy kraj }\end{array}$ & 4.5 & 0 & 0 & $0^{*}$ & 400 & JSC Rusolovo \\
\hline $\begin{array}{l}\text { Construction of Taezhny } \\
\text { iron ore mining and } \\
\text { processing plant, Republic } \\
\text { of Sakha (Yakutiya) }\end{array}$ & 18.7 & 17.1 & 1.6 & $0.09 *$ & 600 & CJSC MMC Timir \\
\hline
\end{tabular}

* - there is no budget financing, or the company is in search of a co-investor (calculated according to the Investment portal of the Far Eastern Federal District [7])

The main problem of the mineral resource base of the iron ore industry in Russia is the significant remoteness of deposits from metallurgical plants. In regions rich in iron ore, there are no large metallurgical capacities. And the areas of concentration of the main steel mills are remote from sources of raw materials and experience an acute ore deficit. In longdistance transportation, the cost of transportation significantly (up to $30 \%$ or more) increases the cost of iron ore raw materials themselves.

Consider the implementation of an investment project in the form of a vertically integrated mining and metallurgical complex due to the fact that the region needs its own ferrous metallurgy $[8,9]$. The objectives of various forms of integration in the mining and 
and challenges of financial and economic independence and security of the main (metallurgical) production; increasing competitiveness in the domestic and foreign markets; implementation of long-term targeted scientific, technical and investment development programs; ensuring and improving product quality; expansion of the assortment and growth in output of products of high technological conversion; modernization of the production base; reduction in production transaction costs.

This project envisages the construction of a metallurgical complex with two modules (with coke technology and direct iron reduction) on the basis of Kimkano-Sutar and Garinsky GOKs and its further work for 50 years as part of a single enterprise. Calculations were made for three options: 1) basic, 2) Advanced Development Territory (ADT), 3) without infrastructure costs (Table 5).

Since the Far Eastern Federal District provides measures of state support for investment projects (according to the program "Socio-economic development of the Far East and the Baikal region" [10]), the corresponding indicators for the second option were calculated on the basis of the ADT. Namely: income tax of 5\% during the first 5 years, and the next 5 years - $12 \%$; land tax $0 \%$ for 5 years; property tax $0 \%$ for 5 years, in the next 5 years $1.1 \%$; for mineral extraction tax, reduction factors were applied to the tax base. For the third option, it is assumed that the costs of creating infrastructure are provided at the expense of state support.

Table 5. The main economic indicators for the operation of the mining and metallurgical complex

\begin{tabular}{|c|c|c|c|c|}
\hline \multirow[b]{2}{*}{ Index } & \multirow{2}{*}{$\begin{array}{c}\text { One } \\
\text { measuring }\end{array}$} & \multicolumn{3}{|c|}{2019 г. } \\
\hline & & base & ADT & $\begin{array}{c}\text { without } \\
\text { infrastructure costs }\end{array}$ \\
\hline Annual volume of metal produced & $\begin{array}{c}\text { million } \\
\text { tons }\end{array}$ & 6 & 6 & 6 \\
\hline Price 1 ton of metal & $\$ / t$ & 580 & 580 & 580 \\
\hline Working time & years & 50 & 50 & 50 \\
\hline Sales proceeds & million \$ & 174000 & 174000 & 174000 \\
\hline Total investment: & million $\$$ & 6924,1 & 6924,1 & 5335 \\
\hline including infrastructure costs & million \$ & 1589 & 1589 & - \\
\hline Net profit & million \$ & 79503 & 83614 & 90961 \\
\hline Number of jobs created & persons & 3047 & 3047 & 3047 \\
\hline Taxes, total: & million \$ & 33903 & 29792 & 35950 \\
\hline $\begin{array}{l}\text { including payments for nature } \\
\text { recovery }\end{array}$ & million $\$$ & 375 & 375 & 375 \\
\hline $\begin{array}{l}\text { payment for the right to use } \\
\text { mineral resources }\end{array}$ & million $\$$ & 1740 & 1575 & 1740 \\
\hline tax on production & million $\$$ & 8352 & 7350 & 8352 \\
\hline property tax & million \$ & 3560 & 2580 & 2743 \\
\hline income tax & million \$ & 19876 & 17912 & 22740 \\
\hline $\begin{array}{l}\text { Net present value (NPV) at a rate of } \\
5 \%\end{array}$ & million $\$$ & 23126 & 26452 & 28684 \\
\hline Internal Rate of Return (IRR) & $\%$ & 13 & 13,81 & 13,91 \\
\hline Profitability Index (PI) & units & 4,34 & 4,82 & 6,38 \\
\hline Payback period & years & 5 & 4 & 4 \\
\hline
\end{tabular}

Calculations have shown that all three options are cost-effective. Considering the position of both the investor and the state, the third option is the most acceptable. So, having spent budget funds on the creation of infrastructure of $\$ 1,589$ million, the state as a result will receive $\$ 35,950$ million in tax revenues for the entire duration of the project. At the same time, the state currently partially finances such projects as the development of the Garinsky iron ore deposit and the construction of a mining and processing complex, as well as the creation of a mining and metallurgical cluster in the Amurskaya oblast (see Table 4). In relation to the calculations made, this represents $25 \%$ of the required investments to create a full-volume steel industry in the region with a high degree of conversion. And as 
enterprises. A zero rate has been introduced for tin mining in the eastern regions of the country for a period of five years, which allows restoring production at previously developed deposits and commissioning new facilities. The tin specialization of the territory of the Russian Far East is, following gold ore, one of the leading specializations. During the period 1990-2014, production at most fields was stopped. In recent years, tin production was carried out periodically only in Khabarovskiy Kray, in Primorskiy Kray it was associated production. At the same time, Russia's annual demand for tin is determined at 7.5 thousand tons. The missing volumes of tin are imported and processed at the Novosibirsk Tin Plant [11]. According to table 4, it is clear that none of the projects related to tin mining has budget support. Their indicators are shown in table 6 .

Table 6. Characteristics of development projects for tin deposits in the Far Eastern Federal District [7]

\begin{tabular}{|c|c|c|c|}
\hline \multirow[b]{2}{*}{ Index } & \multirow[b]{2}{*}{ Units } & \multicolumn{2}{|c|}{ Project } \\
\hline & & $\begin{array}{l}\text { Mastering alluvial tin on } \\
\text { the Tirechtyakh stream }\end{array}$ & $\begin{array}{c}\text { Construction of GOK } \\
\text { Pravourmiiskiy }\end{array}$ \\
\hline Investments & $\begin{array}{l}\text { billion } \\
\text { rubles }\end{array}$ & 1.1 & 4.5 \\
\hline Net present value & $\begin{array}{l}\text { billion } \\
\text { rubles }\end{array}$ & 145 & -84.2 \\
\hline Payback period & years & 6 & 7.3 \\
\hline $\begin{array}{l}\text { The coefficient of } \\
\text { specific efficiency of the } \\
\text { investment project }\end{array}$ & units & 0.5 & 0.99 \\
\hline $\begin{array}{l}\text { Internal Rate of Return } \\
\text { (IRR) }\end{array}$ & $\%$ & 19.1 & 13.1 \\
\hline Discount payback period & years & 10 & - \\
\hline
\end{tabular}

\section{Conclusion}

The main problems that inhibit investment activity in the Far Eastern Federal District, taking into account regional characteristics, include:

- lack of own investment funds of enterprises due to low profitability and a large number of unprofitable industries;

- weak role of the banking system in lending to the real sector of the economy;

- underdevelopment of the stock market, especially regarding sub-federal and municipal borrowing;

- weak development of non-traditional forms of investment (mortgage lending, leasing, etc.).

However, the main problems are the infrastructural support of resource projects and the high costs of their implementation due to remoteness and severe climatic conditions. Especially in these conditions, state support is necessary for the full development of the Far Eastern Federal District. It is advisable to consider additional opportunities for priority federal financing of activities in the Far Eastern Federal District as part of the implementation of national (federal) projects, including using inter-budgetary subsidy mechanisms [12]. To ensure further economic growth, conditions should be created aimed at redistributing financial resources for the development of the real sector, and stimulating the development of manufacturing industries taking into account the potential opportunities and comparative advantages of the region. 
publisher.ru/admin/files/2012-Dabiev-mngr.pdf (date of accessed 20.12.2012)

2. Claudia Perez, Oscar Claveria. Resources Policy, 65 (2020)

3. The volume of exports of Russia. - URL: http://www.ereport.ru/stat.php?razdel=country\&count=russia\&table=execia (date of accessed 25.03.2020)

4. Regions of Russia. Socio-economic indicators. 32, 1204 (2019)

5. V. G. Vologin, A. V. Lazarev. Exploration and protection of mineral resources, 9, 44-50 (2016)

6. M.L.C.M.Henckens, E.C. van Ierland, P.P.J. Driessen and E. Worrell, Mineral Resources: Geological Scarcity, Market Price Trends, and Future Generations. Resources Policy, 49, 102-111 (2016)

7. Investment portal of the Far Eastern Federal District [Electronic resource]. - URL: https://invest.minvr.ru/ru/projects/20 (date of access 03.20.2020)

8. Yu .A. Arkhipova. Formation of vertically integrated production in the mining and metallurgical industry (on the example of the Far Eastern region of the Russian Federation) (2006)

9. Yu. A. Arkhipova, I. A. Kradenykh Mining Information and Analytical Bulletin (scientific and technical journal), S4, 442-452 (2010)

10. The state program of the Russian Federation "Socio-economic development of the Far East and the Baikal region". - URL: http:/gov.garant.ru/document?id=70544078\&byPara=1\&sub=1017 (accessed 02.15.2020)

11. G. I. Arkhipov Mineral resources of the mining industry of the Far East. Strategic assessment of development opportunities (2017)

12. M. V. Milchakov Bulletin of Moscow State Regional University. Series: Natural Sciences, 4, 71-79 (2018) 